\title{
Rajawali Televisi (RTV) Social Media Management
}

\author{
Wahyudi $^{1}$, Nur Kholisoh ${ }^{2}$ \\ \{wahyu.tv@gmail.com ${ }^{1}$,nur.kholisoh@mercubuana.ac.id ${ }^{2}$ \}
}

Universitas Mercu Buana, Jakarta, Indonesia ${ }^{12}$

\begin{abstract}
The era of digital disruption marked by the massive use of social media and digital technology has an impact on real challenges facing the national television industry in Indonesia. Currently television stations not only compete with other television stations but also have to compete with influencers on social media in capturing viewers and advertisements. For the television industry, the presence of social media can be seen as a challenge and an opportunity in carrying out its business processes. Seeing this phenomenon, Rajawali Televisi (RTV) is aware of the great influence of social media as a media for program promotion and distribution of broadcast content. This study aims determine the social media management of RTV. This study uses a qualitative research approach with a case study method and uses the conceptual foundation of Regina Lutrell's The Circular Model of SOME. Data collection techniques in the form of interviews, literature study, and documentation. The results show that currently the use of social media on RTV greatly contributes to building the closeness of the audience to its programs and increasing company revenue obtained from YouTube AdSense and advertising on RTV social media. RTV social media management seeks to pay attention to the aspects of share, optimize, manage, and engage so that social media Facebook, Instagram, Twitter, and YouTube can be used optimally to achieve company goals.
\end{abstract}

Keywords: Social Media, Management, Television

\section{Introduction}

The phenomenon of digital disruption has hit the industries of various sectors. One of the industries most affected by digital disruption is the mass media industry. Digital disruption replaces old technology with digital technology which produces something completely new. Today's media consumption patterns are increasingly leaving conventional media and shifting to digital. The era of digital disruption marked by the massive use of social media and digital technology has an impact on real challenges facing the national television industry in Indonesia. Currently television stations not only compete with other television stations but also have to compete with influencers on social media in capturing viewers and advertisements. Social networks have not only changed television consumption patterns but they have also affected the way in which television channels promote their content through these new tools as they seek a higher level of engagement from their audience [1].

The use of social media in Indonesia continues to grow rapidly from year to year. Social media have become useful tools for audiovisual promotion, especially to reach niche audiences [2]. Quoting the Kumparan.com page, research on social media management platform Hootsuite and social marketing agency We Are Social entitled "Global Digital 
Reports 2020", explained that nearly 64 percent of Indonesia's population is connected to the internet network. In 2020, the number of social media users in Indonesia has reached 160 million, an increase of 8.1 percent or 12 million users compared to last year. That way, the penetration of social media use in Indonesia has reached 59 percent of the total population [3]. Journalistic use of social media for sourcing, distribution and promotion of news comes at a time when the newsroom itself can be said to be in a state of "transition" [4].

The high number of social media users has attracted the attention of the market share to advertise using the services of social media influencers. This has the potential to threaten the decline in television advertising revenue. Viewers are a reacted to social television because of its social aspects (connect on to their peers, conversa on, and second-screen ac vi es) [1]. Social engagement is a complex process driven by multiple factors, particularly, programrelated variables such as affinity, involvement, and genre preferences, as well as individuals' innovativeness trait [5]. Social media is a medium on the internet that allows users to represent themselves and interact, collaborate, share, communicate with other users, and form social bonds [6]-[8]. According to Abdullah and Puspitasari, the growing number of social media users has an effect on the development of mass media including television media [9].

It cannot be denied that the presence of social media has brought opportunities and challenges to conventional television media. Television stations have a growing repertoire of social media and other connectivity tools with which to engage their viewers, but that stations in larger markets are making fuller use of interactive technologies [10]. For the television industry, the presence of social media on the one hand can be seen as an opportunity in carrying out its business processes. If the current trends are any indications, old television shows and rerun culture more broadly will persist in whatever forms 'television' takes in the future [11]. Social TV is defined as real-time backchannel communication on social networking sites (SNSs) during a live television broadcast [12]. Now all national television stations in Indonesia have social media accounts and have a special team to manage them. Not only the company's official corporate account, but also top programs on the television station now have social media accounts. Through various social media such as Instagram, Facebook, Twitter and YouTube, television stations can market their programs. Comments from social network sites (SNSs) also varied in their use of appropriate grammatical form and internet lingo [13].

Social media has become a powerful tool for promoting television stations' events. Even YouTube social media should be seen as a new opportunity. Social media are an important opportunity for communication and an efficient media promotion tool. Intelligent use of social media tools to promote media content helps to increase site traffic, build mass media image, and increase its reach [14]. The television media business is now required to converge with internet-based media. Stations are embracing social media as a means of connecting with news consumers and raising their newsrooms' profile in the community, and are encouraging their news staff members to have an individual social media presence [15]. Conventional television media must manage digital content to maintain their business, while not losing their audience. Currently national television stations in Indonesia are competing in managing social media as a strategy to increase revenue for the company. However, stations that offered news items also seldom promoted their regular newscasts [16].

The media need to develop new business models as a response to the massive technological developments that have occurred. In practice, the media business must take new approaches that associate internet technology with their business [17]. For the television industry, social media management is a form of business development model in the face of 
the digital era. The presence of digital media such as YouTube, Instagram, Twitter, Facebook or other digital applications can provide its own advantages beyond television ad revenue [18]. The social sphere presents organizations with a vast array of tools, communities, and social sites that they can use to interact with consumers. The Circular Model of SoMe for Social Communication (Share, Optimize, Manage, Engage) is a primary component of the social media research and planning phase [19].

Among the national television stations in Indonesia, Rajawali Televisi (RTV) is an interesting station to observe in its social media management. Quoting http://www.kpi.go.id, RTV is considered the most representative and safe TV viewing for children. This was conveyed by the Central Indonesian Broadcasting Commission (KPI) when conducting an annual evaluation of a TV broadcasting institution with the RTV network at the Central KPI Office, Thursday (20/2/2020). As television, which is well known for its children's programs, it certainly has its own challenges in terms of managing social media. The process of share, optimize, manage, and engage in social media management that involves many children as audiences or followers clearly requires special tactics. In the midst of its young age, RTV shows its seriousness in managing digital platforms, especially social media. In 2019 RTV received the Gold Silver Button award from YouTube for the official Rajawali Televisi YouTube Channel. Currently, Rajawali Televisi is a television station that has the highest number of children's YouTube channels among other national television stations in Indonesia.

In today's digital era, television stations must play social media as a strategy to increase revenue for companies. This is because television station revenue is not only obtained from on air advertisements but also from social media it owns. YouTube media for example, by redistributing online broadcast content to YouTube channels, television stations can reap the benefits obtained from YouTube AdSense. In addition, now advertisers are not only posting their products on television shows but also on social media accounts owned by the TV station. Rajawali Televisi currently manages Instagram, Facebook, Twitter and YouTube accounts. Apart from corporate accounts, RTV also creates accounts for the featured programs broadcast on the television. Social media management is not only as a media for program promotion but as a way to provide access for viewers of online television broadcasts on YouTube. RTV's use of social media is to strengthen the function of the media while at the same time expanding the audience network through a more diverse distribution of information. This study aims to see how social media management is carried out by RTV.

Research on social media in the television industry was carried out by Rangga Saptya Mohamad Permana and Jimi Narotama Mahameruaji [20] Padjajaran University Bandung in the journal Communication and Media Studies Vol. 23 No. 1 (June 2019) Pages: 21 - 36. The research entitled NET.TV New Media Utilization Strategy tries to analyze the use of new media as the main platform for NET.TV to compete for the audience market in Indonesia. The social media management activities of the Instagram account have been researched by Rizky Pratama Hajati, Susie Perbawasari and Hanny Hafiar, 2018, Universitas Padjajaran in the journal Meta Communication; Journal of Communication Studies Vol 3 No. 2 September 2018.

Taking the title Social Media Activity Management for Instagram @ indonesiabaik.id, this research aims to find out how the social media management of Instagram @ indonesiabaik.id through the share, optimize, manage, and engage stages. Research on social media management, especially Instagram, was conducted by Cholidah Astri Pertiwi, Dinda Rakhma Fitriani and Budi Santoso [21], Gunadarma University. Research published in the journal International Journal of Multicultural and Multireligious Understanding Vol. 6 
(February 2019) Page: 33-42 entitled the research title Smart City through Social Media: In Creating Good Governance in the Government of West Java. Research on television media in the internet era was conducted by Aceng Abdullah and Lilis Puspitasari [9], 2018 Padjadjaran University in the journal ProTVF, Volume 2, Number 1, March 2018 with the title television media research in the Internet Age. The results of the study explained that the existence of television in the internet era has begun to be disrupted by the existence of social media.

\subsection{Social Media}

Andreas Kaplan and Michael Haenlein [22] define social media as a group of internetbased applications built on the foundation of Web 2.0 ideology and technology, and support the exchange and exchange of user-generated content. Social media users or it can be called this user can communicate or interact, send messages, both text messages, pictures, audio to video, share or share, and also build networks or networking. However, in general, the definition of social media is online media. Social media is an online media where users can communicate and interact with each other [23], [24]. So social media is a channel or means for social interaction that is carried out online via the internet network.

\subsection{Social Media Characteristics}

The characteristics of social media are not much different from cyber media because social media is one of the platforms for cyber media. However, according to Nasrullah [6] social media has special characters, namely: network, information, archive, interactivity, simulation of society and user-generated content.

\subsection{The Circular Model of SoMe for Social Communication}

Regina Luttrell created a model for planning communication on social media, namely The Circular Model of SoMe with the aim of making it easier for social media practitioners to communicate interactions on social media [19]. Here is an explanation of The Circular Model of SoMe by Regina Luttrell: (1) Share: Where is my audience? What types of networks are they engaging on? Where should we be sharing content? It is vital social media strategists understand how and where their consumers interact. This is a company's opportunity to connect, build trust, and identify channels that allow for true interactions; (2) Optimize: What type of content should be shared? Do we have brand influencers and advocates? Where are we being mentioned and how? To optimize any conversation listening is paramount.

A strong communication plan that optimizes your content results in maximum impact of messaging, brand, and value; (3) Manage: What relevant messaging should we manage, monitor, and measure? An organization must listen what is being said and learn from the conversations being shared; and (4) Engage: Whom should we engage with, when, and how. Engaging in conversations with your consumers.

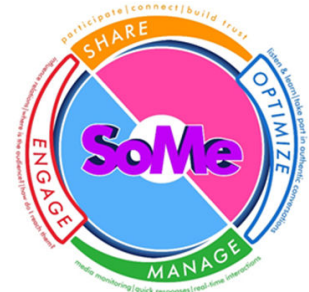

Fig 1. The Circular Model of SoMe [19] 


\section{Research Method}

This study uses a qualitative research approach with a case study method. The advantages of case studies lie in the refining theory and the complexity of the issues offered that can be used as research material in the future, as well as evidence of the limitations of the generalizability principle [25]. The descriptive-qualitative case study method was chosen because the writer collected facts about the social media management of Rajawali Televisi.

In this study, the authors used data collection techniques in the form of interviews, literature studies, and documentation. In the procedure of sampling / selecting informants in the research, the authors used a purposive procedure. A purposive procedure is carried out by determining which groups of participants become informants according to selected criteria that are relevant to a particular research problem [26]. The criteria for informants selected in this study were (1) national television broadcasting practitioners; (2) RTV employees (3) Participate in formulating RTV's social media management strategy.

\section{Results and Discussion}

In the era of digital disruption when most of the distribution of information takes place in cyberspace, the television industry is facing competition with digital media that is relatively more accessible. This requires the national television industry to continue to present innovations, both in broadcast programs and in broadcast media, by providing access to watch multiplatform television broadcasts. In addition, television stations must be creative in promoting programs through social media in order to increase the number of viewers which has implications for rating achievements. The use of social media is one of the television industry's strategies in facing the digital era.

Seeing this phenomenon, Rajawali Televisi (RTV) is aware of the great influence of social media as a media for program promotion and distribution of broadcast content. In the face of the era of digital disruption that is hitting the television industry, RTV has a strategic policy by forming a Creative Digital Department which is tasked with managing RTV's social media and digital platforms. Social media is considered to be an important medium for marketing programs and divergence (dissemination) of program content that has an impact on increasing company revenue. The choice of social media as a television station marketing media is in line with the characteristics of social media itself. There are at least two characteristics of social media that make this media used for many things, namely userdefined content (UGC) and as a medium for disseminating information / content quickly and easily (share / sharing).

The presence of social media such as Youtube, Instagram, Twitter, Facebook or other digital applications can provide its own advantages beyond television ad revenue [18]. Currently the use of social media on RTV greatly contributes to increasing program awareness and increasing company revenue obtained from YouTube adsense and brand owners who post their products on RTV social media. As stated by the Head of Creative Digital Department RTV, Wahyu Nurtjahyono in the following interview excerpt.

"The use of social media and digital content on RTV has a huge impact in raising program awareness, because now the era is digital. Through social media platforms and digital content, it can provide another angle for viewers or viewers in how to enjoy a showIf you look at the development of social media on RTV, it has a very positive impact. Social 
media management on RTV can be used as a method to get revenue. Now the strategy of the marketing team when offering advertising spots on TV is also offering advertising packages on social media. For example, product A posts advertisements on TV for three months, maybe on social media platforms, it can be more than three months according to the price of the ad package and the contract. In addition, the revenue obtained from Youtube adsense on $R T V$ has a quite significant increase from last year, and this year it continues to rise." (Wahyu Nurtjahyono, RTV)

The current era of digital disruption, television stations in Indonesia are not only competing in broadcasting on air but also in managing social media platforms. The RTV digital team has a special strategy and planning in managing its social media platforms.

\subsection{Share Process}

The first aspect of The Circular Model of Some is share. According to Regina Luttrell, it is very important for social media practitioners to understand how and where their consumers interact. This is a company opportunity to connect, build trust, and identify channels that allow the right interactions [19]. Currently, RTV focuses on managing four types of social media to market its programs, namely Facebook, Instagram, Twitter, and Youtube. Through this social media platform, RTV tries to build the trust and closeness of viewers to its programs. Meanwhile, the social media Youtube is also used as a channel for disseminating broadcast content (divergence), both in-house programs and out-house production. The use of YouTube social media aims to enable people to access broadcast content anytime and anywhere. This is in accordance with Shahril Halim's opinion, which states that the divergence (dissemination) of media content by utilizing the YouTube channel will make television viewers have many choices in using media according to the needs of society [27]. The more access to the Rajawali Televisi Youtube channel also has an impact on the increase in company revenue obtained from Youtube adsense.

Based on the results of interviews conducted by researchers regarding the sharing process in managing RTV social media, currently the most prioritized platform for sharing promotional content for RTV programs is Instagram social media, with the order of Instagram, Facebook, Twitter, and Youtube. Youtube social media functions more as a medium for distributing TV broadcast content. However, currently the social media that is considered the most contributing in increasing company revenue is Youtube.

"Facebook, Instagram, Twitter and Youtube all serve to promote the program and make money. The difference is the number of percentages. The highest share percentage of program promo content is on Instagram social media, with the order of Instagram, Facebook, Twitter and Youtube. Meanwhile, the most revenue is obtained from social media Youtube. If asked about the revenue generated from Youtube RTV in one year is able to generate billions of rupiah. It is proven by the limited time, nowadays many people access Youtube to view shows that have not been watched on TV. This also affects the revenue from Youtube" (Wahyu Nurtjahyono, RTV)

\subsection{Optimize Process}

The second aspect of The Circular Model of Some is to optimize. In optimizing content (optimize) social media, the RTV social media team tries to create a variety of creative content to be shared with followers or subscribers. The content uploaded on the social media Facebook, Instagram, and Twitter RTV is usually the same, the difference lies in the editorial or caption writing adjusted to the character of each of these social media. The types of content shared on the social media Facebook, Instagram, and Twitter RTV include program 
promo flyers, quizzes, video campaigns, program clips or teasers, info updates, media partners / sponsorships and others.

Meanwhile, the type of content uploaded on the YouTube social media is certainly different from the social media Facebook, Instagram and Twitter. Based on the interviews that have been conducted, the types of content uploaded on YouTube RTV social media consist of in-house programs, out-house production $(\mathrm{PH})$ programs, original content, and program promos.

"The types of content uploaded on the RTV Youtube channel consist of: 1) In-house programs, which are programs produced by RTV. 2) Out-house production (Acquisition program), a program purchased from a production house (PH). In uploading the content of the out-house production or acquisition program, there is a contract agreement between the RTV station and the Production House, such as the licensce term and the distribution of revenue obtained from Youtube. The percentage of revenue sharing obtained from Youtube depends on the agreement between RTV and PH. 3) Original content, namely content produced by the RTV digital team that does not broadcast on air, only broadcast on the digital RTV platform. The content is in the form of behind the scenes, vlogs, challenges, parodies and others. 4) Program promotions, promotional content for programs broadcast on RTV"(Wahyu Nurtjahyono, RTV).

\subsection{Manage Process}

The third aspect of The Circular Model of Some is manage. Based on the results of the interviews obtained, in the manage process, the RTV social media team always tries to see, respond to, and analyze netizen comments on RTV's social media accounts regarding criticism, suggestions, questions and input on RTV shows or about RTV companies. Another step that is no less important is monitoring the development of the number of followers and followers' impressions of the content by making a weekly report. This is in accordance with Luttrel's [19] statement, according to him, monitoring media can calculate results and understand metrics that appear on social media.

In conducting media monitoring, the social media team also analyzes top posts and low posts on social media accounts for Facebook, Instagram and Twitter. Besides that, it also summarizes positive and negative comments (positive \& negative issues) on these social media accounts [23]. Comments or program input can be used as evaluation material to be submitted to the production team or programming team. As stated by the Section Head of Social Media for RTV, Widaywati in the following interview excerpt.

"The social media team must always respond to and analyze netizen comments on social media accounts owned by RTV. So if you respond to comments it is mandatory. For example, questions outside the RTV program, such as job vacancies, we will follow up to the relevant department, submit these questions to HR. Every Friday we make a weekly report as a place to evaluate. In the weekly report there are reports of the top three posts from Instagram, Facebook, and Twitter, besides that there are also low posts. In addition, there are reports on any positive and negative issues for one week. Then we think about how to avoid negative issues. The social media team must always work together with the production team or programming team. For example, the acquisition programing team saw that the program on onair share had dropped or had fallen, please try on social media to intensify the promotion or create another campaign ". (Widyawati, RTV)

Unlike the social media Facebook, Instagram and Twitter, many videos on the RTV Youtube channel have their comments disabled. This is due to the YouTube policy that 
closes (disables) the comments column on children's videos. In June 2020 RTV manages more than 20 Youtube channels with a total of millions of subscribers.

\subsection{Engange Process}

The final aspect of The Circular Model of Some is Engange. The engage stage is an important stage in managing social media. Based on the results of the interviews obtained, in the RTV social media engagement process, the social media team approaches stakeholders, namely influencers (celebrities) and audiences, such as:

\subsubsection{Influencers}

One of the strategies carried out by the RTV social media team in increasing engangement is to involve the performers of the RTV program to share program promo content on their social media accounts. In certain cases, the influencers involved are influencers outside of the program performers. In addition, the RTV digital team also often makes videos inviting to subscribe to RTV's YouTube channels by involving artists who perform RTV programs. The video invitation to subscribe to the YouTube channel that involves public figures certainly has an effect on increasing public awareness of the Youtube media platform owned by RTV. The following is an excerpt from the interview delivered by the Section Head of Social Media for RTV, Widaywati.

"Usually we involve internal artists who often fill in on RTV programs to promote our programs. In certain cases, we have also used the influncer outside the program actor. Influencer price levels vary according to what has been agreed. So we can't choose influencers carelessly, we have to sort that want what the company or client wants. When sorted they will be selected again according to budget and others. So after that we will coordinate with the manager or the influencer himself. After it was agreed upon, we briefed what the influncer had to do in accordance with the agreement and there was legal legality". (Widyawati, RTV).

\subsubsection{Audiences}

The RTV social media team is working with the off air promo team to increase social media engagement. For example, when the off air promo team conducts events at schools or events that involve a large audience, the off air promo team will make a quiz or game with prizes on the condition that participants who participate must follow and subscribe to RTV's social media. This is in accordance with Luttrel's [19] statement in social media management, involving audiences and influencers is a very important component in social media strategy.

\section{Conclusions}

The presence of social media has formed a new business model in the broadcast industry. If in the past the program's success was only seen from ratings and sponsorships on television, now the success of a program can also be measured based on revenue from the program obtained from social media platforms. RTV shows its seriousness in managing social media platforms. The use of social media on RTV has implications for building audience closeness to its programs and increasing the company's revenue outside of television ad revenue. Currently the most prioritized platform for sharing promotional 
content for RTV programs is Instagram social media, with the order of Instagram, Facebook, Twitter and YouTube. YouTube social media functions more as a medium for distributing TV broadcast content. In optimizing social media content (optimize), the RTV social media team strives to create a variety of creative content to become followers or subscribers. In the process of managing, the social media team always tries to view, blog, and analyze netizen comments on RTV's social media accounts. Routine media monitoring is carried out as an evaluation material with the programming and production teams. In increasing engagement, the RTV social media team approached stakeholders, namely influencers (celebrities) and audiences.

RTV social media management seeks to pay attention to the aspects of share, optimize, manage, and engage so that social media Facebook, Instagram, Twitter, and YouTube can be used optimally to achieve company goals. Rajawali Televisi in the future must continue to innovate in the management of social media and other digital platforms in order to compete with private television stations in Indonesia.

\section{References}

[1] F. Segado-Boj, E. Fernández-Gómez, and others, "Social media and television: a bibliographic review based on the Web of Science," 2015.

[2] J. Mart।'in-Quevedo, E. Fernández-Gómez, and F. Segado-Boj, "How to engage with younger users on Instagram: A comparative analysis of HBO and Netflix in the Spanish and US markets,” Int. J. media Manag., vol. 21, no. 2, pp. 67-87, 2019.

[3] "Riset: 64\% Penduduk Indonesia Sudah Pakai Internet - kumparan.com." [Online]. Available: https://kumparan.com/kumparantech/riset-64-penduduk-indonesia-sudah-pakai-internet-

1ssUCDbKILp. [Accessed: 14-Dec-2020].

[4] V. Sacco and D. Bossio, "DON'T TWEET THIS! How journalists and media organizations negotiate tensions emerging from the implementation of social media policy in newsrooms," Digit. Journal., vol. 5, no. 2, pp. 177-193, 2017.

[5] M. Guo and S. M. Chan-Olmsted, "Predictors of social television viewing: How perceived program, media, and audience characteristics affect social engagement with television programming," J. Broadcast. Electron. Media, vol. 59, no. 2, pp. 240-258, 2015.

[6] R. Nasrullah, "Media sosial: Perspektif komunikasi, budaya, dan sosioteknologi," Bandung: Simbiosa Rekatama Media, vol. 2016, p. 2017, 2015.

[7] T. Sulistyaningtyas, J. Jaelani, and Y. Suryani, "Power of knowledge and community social class above Covid-19 pandemic information on social media,” J. Komun. Ikat. Sarj. Komun. Indones., vol. 5, no. 1, pp. 52-62, 2020.

[8] N. Hasfi and T. Rahardjo, "The disable people virtual communities in social media from the perspective of public sphere theory,” J. Komun. Ikat. Sarj. Komun. Indones., vol. 4, no. 2, pp. 65-76, 2019.

[9] A. Abdullah and L. Puspitasari, "Media televisi di era internet," ProTVF, vol. 2, no. 1, pp. 101-110, 2018.

[10] D. A. Ferguson and C. F. Greer, "Reaching a moving target: How local TV stations are using digital tools to connect with generation C," Int. J. Media Manag., vol. 18, no. 3-4, pp. 141$161,2016$.

[11] D. Kompare, "Reruns 2.0: Revising repetition for multiplatform television distribution," J. Pop. Film Telev., vol. 38, no. 2, pp. 79-83, 2010.

[12] J. S. Lim, Y. Hwang, S. Kim, and F. A. Biocca, "How social media engagement leads to sports channel loyalty: Mediating roles of social presence and channel commitment," Comput. Human Behav., vol. 46, pp. 158-167, 2015.

[13] S. Gearhart and S. Kang, "Social media in television news: The effects of Twitter and 
Facebook comments on journalism," Electron. News, vol. 8, no. 4, pp. 243-259, 2014.

[14] M. Kitsa and I. Mudra, "Social Media Tools for TV Programmes Promotion," Commun. Today, vol. 9, no. 2, pp. 56-73, 2018.

[15] S. Lysak, M. Cremedas, and J. Wolf, "Facebook and Twitter in the newsroom: How and why local television news is getting social with viewers?," Electron. News, vol. 6, no. 4, pp. 187207, 2012.

[16] C. F. Greer and D. A. Ferguson, "Using Twitter for promotion and branding: A content analysis of local television Twitter sites," J. Broadcast. Electron. Media, vol. 55, no. 2, pp. 198-214, 2011.

[17] H. Haryati, "Ekologi Media di Era Konvergensi," Observasi, vol. 10, no. 2, p. 220598.

[18] A. Nugroho and M. Syas, "MEDIAMORFOSIS TV ONE PADA ERA MEDIA BARU," J. Ranah Komun., vol. 3, no. 1, pp. 23-33, 2019.

[19] R. Luttrell, Social media: How to engage, share, and connect. Rowman \& Littlefield, 2018.

[20] R. S. M. Permana and J. N. Mahameruaji, "STRATEGI PEMANFAATAN MEDIA BARU NET. TV UTILIZATION OF NEW MEDIA STRATEGY OF NET. TV."

[21] C. A. Pertiwi, D. R. Fitriani, and B. Santoso, "Smart City through Social Media: In Creating Good Governance in the Government of West Java," Int. J. Multicult. Multireligious Underst., vol. 6 , no. 10 , pp. $33-42,2019$.

[22] A. M. Kaplan and M. Haenlein, "Users of the world, unite! The challenges and opportunities of Social Media," Bus. Horiz., vol. 53, no. 1, pp. 59-68, 2010.

[23] R. Novendri, A. S. Callista, D. N. Pratama, and C. E. Puspita, "Sentiment Analysis of YouTube Movie Trailer Comments Using Naïve Bayes," Bull. Comput. Sci. Electr. Eng., vol. 1, no. 1, pp. 26-32, 2020, doi: 10.25008/bcsee.v1i1.5.

[24] F. F. Kurniawan, F. R. Shidiq, and E. Sutoyo, "WeCare Project: Development of Web-based Platform for Online Psychological Consultation using Scrum Framework," Bull. Comput. Sci. Electr. Eng., vol. 1, no. 1, pp. 33-41, 2020, doi: 10.25008/bcee.v1i1.6.

[25] R. E. Stake, N. K. Denzin, and Y. S. Lincoln, "Handbook of qualitative research," SAGE, Londres, 1994.

[26] B. M. Bungin, Konstruksi sosial media massa: kekuatan pengaruh media massa, iklan televisi dan keputusan konsumen serta kritik terhadap Peter L. Berger \& Thomas Luckmann. Kencana, 2011.

[27] S. Halim, A. Sujoko, and Antoni, "STRATEGI STASIUN TV9 LOMBOK DI ERA DISRUPSI," KOMUNIKE, vol. 10, no. 2, pp. 153-170, 2018, doi: 10.20414/jurkom.v10i2.677. 